Pena Guitian, J., Varela Bujan, J.M. \& Gomez Vidal, E. (1963) Sobre la patologia de las immunoglobulinas. Una revision, con aportacion de un caso de agammaglobulinemia por avsenci de las fracciones beta $2 \mathrm{~A}$ y beta $2 \mathrm{M}$. Rev. Esp. Pediat. 19, 223.

Pernod, J. \& Kermarec, J. (1966) Les agammaglobulinémies et leurs manifestations respiratoires. Presse Méd. 74, 2411.

Pernod, J., Saint Blancard, J., Raby, C., Reynier, C. \& MeyrueY, M.H. (1966) Les agammaglobulinémies de l'adulte et leurs manifestations pulmonaires. J. franc. med. Chir. Thorac. 20, 131.

Peterson, R.D., Cooper, M. \& Good, R.A. (1965) The pathogenesis of immunologic deficiency disease. Amer. Med. 38, 579.

Rockey, J.H., Hanson, L.A., Heremans, J.F. \& Kunkel,
H.G. (1964) Beta-2A aglobulinemia in two healthy men. J. Lab. clin. Med. 63, 205.

Rosen, F.S. \& Bougas, J.A. (1963) Acquired dysgammaglobulinemia; elevation of the 19S gamma-globulin and deficiency of the $7 \mathrm{~S}$ gamma-globulin in a woman with chronic progressive bronchectasis. New Engl. J. Med. 269, 1336.

Siguier, F., Betourne, Cl., Levy, R., Hartman, L., Guedon, J. \& RoBon, P. (1965) Les agammaglobulinémies dietes 'acquises' de l'adulte avec splénomégalie. Sem. Hop., Paris, 13, 784.

Werner, F.B., Asofsky, R., LidDy, T.J., TANAKa, Y., ROWE, D.S. \& FAHEY, J.L. (1965) An antibody deficiency syndrome. Selective immunoglobin deficiency with reduced synthesis of $\gamma$ and $\alpha$-immunoglobulin polypeptide chains. Amer. J. Med. 39, 319.

\title{
Correspondence
}

\section{Modern trends in leprosy}

SIR - The statement in the paper by Jamison (Postgrad. med. J., 1969, 45, 409): 'To-day in the United Kingdom no official figures are published . . . is incorrect, since from time to time such figures are published.

The latest figures were quoted in a ministerial reply to a question in the House of Commons on 27 November 1968, and quoted in Leprosy Review,
$1969,40,65$, as follows:

'By the end of 1967, 196 patients were reported to have been cured out of a total of 732 notified since 1951. Of the 357 patients remaining on the register at the end of 1967, 196 were known to be quiescent, but treatment was continuing as a precaution against recurrence.'
Consultant Adviser in Leprosy to the Department of Health and Social Security
S. G. BROWNE O.B.E., M.D., F.R.C.S., F.R.C.P. 